\title{
Melt ponds on Arctic sea ice determined from MODIS satellite data using an artificial neural network
}

\author{
A. Rösel ${ }^{1,2}$, L. Kaleschke ${ }^{1}$, and G. Birnbaum ${ }^{3}$ \\ ${ }^{1}$ Institute of Oceanography, University of Hamburg, Bundesstr. 53, 20146 Hamburg, Germany \\ ${ }^{2}$ Max Planck Institute for Comparative and International Private Law, Mittelweg 187, 20148 Hamburg, Germany \\ ${ }^{3}$ Alfred Wegener Institute for Polar and Marine Research, Am Handelshafen 12, 27570 Bremerhaven, Germany \\ Correspondence to: A. Rösel (anja.roesel@zmaw.de)
}

Received: 26 September 2011 - Published in The Cryosphere Discuss.: 27 October 2011

Revised: 18 March 2012 - Accepted: 19 March 2012 - Published: 3 April 2012

\begin{abstract}
Melt ponds on sea ice strongly reduce the surface albedo and accelerate the decay of Arctic sea ice. Due to different spectral properties of snow, ice, and water, the fractional coverage of these distinct surface types can be derived from multispectral sensors like the Moderate Resolution Image Spectroradiometer (MODIS) using a spectral unmixing algorithm. The unmixing was implemented using a multilayer perceptron to reduce computational costs.

Arctic-wide melt pond fractions and sea ice concentrations are derived from the level 3 MODIS surface reflectance product. The validation of the MODIS melt pond data set was conducted with aerial photos from the MELTEX campaign 2008 in the Beaufort Sea, data sets from the National Snow and Ice Data Center (NSIDC) for 2000 and 2001 from four sites spread over the entire Arctic, and with ship observations from the trans-Arctic HOTRAX cruise in 2005. The root-mean-square errors range from $3.8 \%$ for the comparison with HOTRAX data, over $10.7 \%$ for the comparison with NSIDC data, to $10.3 \%$ and $11.4 \%$ for the comparison with MELTEX data, with coefficient of determination ranging from $R^{2}=0.28$ to $R^{2}=0.45$. The mean annual cycle of the melt pond fraction per grid cell for the entire Arctic shows a strong increase in June, reaching a maximum of $15 \%$ by the end of June. The zonal mean of melt pond fractions indicates a dependence of the temporal development of melt ponds on the geographical latitude, and has its maximum in mid-July at latitudes between $80^{\circ}$ and $88^{\circ} \mathrm{N}$.
\end{abstract}

Furthermore, the MODIS results are used to estimate the influence of melt ponds on retrievals of sea ice concentrations from passive microwave data. Results from a case study comparing sea ice concentrations from ARTIST Sea
Ice-, NASA Team 2-, and Bootstrap-algorithms with MODIS sea ice concentrations indicate an underestimation of around $40 \%$ for sea ice concentrations retrieved with microwave algorithms.

\section{Introduction}

In boreal summer, melt ponds are a common feature on Arctic sea ice and they can cover up to 50 to $60 \%$ of the sea ice area (Fetterer and Untersteiner, 1998; Eicken et al., 2004). On a flat topography of first-year ice and in an early melt stage the melt pond fraction can even rise up to $90 \%$ (Perovich et al., 2011a). Melting caused by shortwave insolation and surface air temperatures above the freezing point during summer results in the development of melt ponds on the sea ice surface and a decrease of the surface albedo from approximately 0.8 to 0.5 which excites additional heat uptake (Curry et al., 1995; Perovich and Tucker, 1997). The appearance of melt ponds has a significant influence on Earth's radiation balance (Maslanik et al., 2007; Perovich et al., 2007; Nicolaus et al., 2010) and therefore also an impact on the strength of the ice-albedo feedback (Tschudi et al., 2008). In order to better constrain the role of sea ice for the Arctic amplification and Earth's climate system, it is important to quantify the large-scale distribution of melt ponds (e.g. Holland et al., 2006; Eisenman and Wettlaufer, 2009; Notz, 2009; Tietsche et al., 2011; Serreze, 2011; Serreze et al., 2011; Kurtz et al., 2011; Perovich et al., 2011b). 
Several field experiments and ship observations at different locations in the Arctic Ocean aimed at the study of albedo and optical properties of melt ponds (Morassutti and LeDrew, 1996; Perovich et al., 2002a), as well as distribution and size of the ponds (El Naggar et al., 1995; Perovich et al., 2002b, 2009; Sankelo et al., 2010; Nicolaus et al., 2010). The Russian ice atlas compiled by Romanov (1993, 1995) includes pan-arctic pond coverage estimates based on Russian overflights and surface observations.

Although the potential of different optical properties of ponded sea ice in comparison to bare or snow-covered sea ice for satellite applications was proposed already by Grenfell in 1977, the first implementations were published 20 years later by Tschudi et al. (1997, 2001, 2008); Markus et al. (2003) and Rösel and Kaleschke (2011). While these studies discuss the feasibility of deriving melt pond fractions from satellite data for specific examples, to our knowledge, no satellite derived Arctic-wide, multi-annual melt pond data set exists.

Many spectral and total albedo values for various surface types are given in the literature (e.g. Grenfell and Maykut, 1977; Grenfell and Perovich, 1984; Warren, 1982; Perovich, 1996; Perovich et al., 2002b; Brandt et al., 2005). The values range from 0.06 for open water to 0.29 for mature melt ponds to 0.87 for new snow.

The date of melt onset is related to the amount of solar energy absorbed by the surface (Perovich et al., 2007). Therefore, a zonal onset of the first melt processes is observable, starting in mid-April in the southern Arctic regions like Bering Sea and Hudson Bay. In the Central Arctic, first melting starts in June (Markus et al., 2009). In mid-June, a significant fraction of sea ice is already covered by melt ponds (Perovich et al., 2007).

Melt pond development starts with the melting of snow. Melt water of snow and ice is collecting in surface depressions and and other surface deformation features. Compared to the much more irregular surface topography of multi-year ice, the plane and flat surfaces of first-year ice have the potential to host large and extended melt pond areas (Fetterer and Untersteiner, 1998; Eicken et al., 2004). As melting develops, pond water drains through porous ice and cracks (Eicken et al., 2002). Yackel et al. (2000) also describe the pond properties and distribution on multi-year ice as smaller, deeper, and more numerous than on first-year ice. The heat transfer due to convection in water exceeds the one of ice. Additionally, the lower albedo of ponded ice allows a higher penetration of heat into the ice. Both factors yield to a 2-3 times higher melt rate beneath ponds compared to the melt rate of bare ice (Fetterer and Untersteiner, 1998). Hence, the ponds deepen and can even melt through the ice layer. With the increasing depth of the ponds, also the diameter decreases (Fetterer and Untersteiner, 1998). Melt ponds are nearly salt free and the density maximum of the ponded water lies well above the freezing point. This means that radiative heating favors convection within the pond: the warmer water will sink down and causes further melting. Convection and mix- ing of the water is further influenced by wind (Fetterer and Untersteiner, 1998; Eicken et al., 2002). Freeze-up starts in late August or early September, caused by low air temperatures, and melt pond fraction decreases. The start of snowfall after the freeze-up will cover the melt ponds and the albedo of the surface rises.

This study is based on a retrieval method for the melt pond fraction from Moderate Resolution Image Spectroradiometer (MODIS) data, founded on spectral unmixing into different surface fractions, published by Tschudi et al. (2005, 2008). We implement an additional constraint to obtain surface fractions in the range between zero and one and use an artificial neural network (ANN) to speed up the processing of large MODIS data sets.

The overall goal of this study is to quantify the surface fractions for melt ponds, open water, and snow and ice for the entire Arctic region for a time period from 2000-2011. Further studies on the results have already been performed and are presented in Rösel and Kaleschke (2012).

This paper is structured as follows: First, a characterization of the MODIS data used in this study and the data handling is given; additionally, the data used for validation are presented. This is followed by a description of the method of retrieving the melt pond fraction and the sea ice concentration. This includes the generation of a training and a test data set as well as the neural network set-up. Subsequently, validation studies are presented. The last chapter provides a discussion and conclusions.

\section{Data}

Acquisition of MODIS data aboard "Terra" began in 1999 and aboard "Aqua" in 2002, continuing through today and providing complete spatial coverage of the Arctic Ocean for the past twelve melt cycles. The Arctic Ocean is defined here as the area northward $60^{\circ} \mathrm{N}$, excluding land. MODIS measures in 36 spectral bands, ranging from $0.4 \mu \mathrm{m}$ to $14.4 \mu \mathrm{m}$ with a resolution from $250 \mathrm{~m}$ to $1 \mathrm{~km}$.

We use the MOD09A1 weekly surface reflectance data product with a spatial resolution of $500 \mathrm{~m}$ to retrieve the MODIS melt pond fraction. Effects of atmospheric scattering and absorption are corrected in the MOD09 products. Additionally, a correction of the bidirectional reflectance distribution function (BRDF) is applied (Vermonte et al., 2008). For the validation studies we use the MOD09GA daily surface reflectance product.

For the analysis of the data we reproject the original MODIS tiles into a polar stereographic projection, mosaic them, and apply a cloud-mask as well as a land-mask, which both are contained in the MOD09 product. For the comparison with the validation data, we generate true color composites using the spectral band combination 2-4-3 of the MODIS level $1 \mathrm{~B}$ product. 


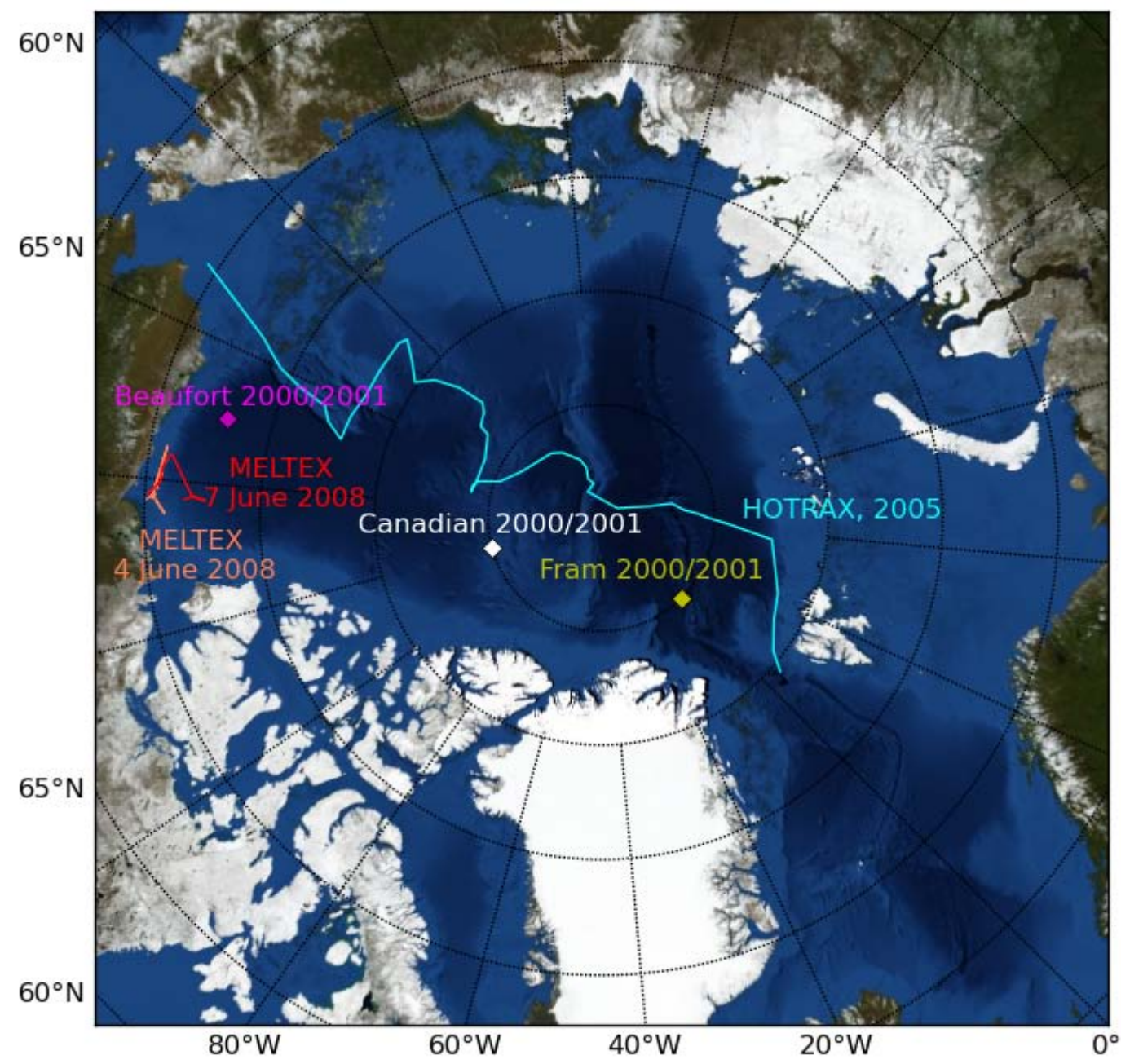

Fig. 1. Tracks, locations and dates of validation data sets. Detailed descriptions are given in the text.

For validation we use the results of the melt pond observations from the HOTRAX 2005 cruise (Perovich et al., 2009), the melt pond data set from the National Snow and Ice Data Center (NSIDC) (Fetterer et al., 2008), and the results of the aircraft campaign MELTEX ("Impact of melt ponds on energy and momentum fluxes between atmosphere and sea ice") conducted by the Alfred Wegener Institute for Polar and Marine Research (AWI) in May and June 2008 over the Beaufort Sea (Birnbaum et al., 2009) (see Fig. 1).

The MELTEX campaign aimed to improve the quantitative understanding of the impact of melt ponds on radiation, heat, and momentum fluxes over Arctic sea ice. For this purpose, the BASLER BT-67 type aircraft POLAR 5 was employed, which had a downward-looking digital photo camera aboard. Weather conditions at the end of May were mainly characterized by cold-air advection from the inner parts of the Arctic towards the coast of the southern Beaufort Sea. These cold air flows caused a refreezing of most melt ponds, which were still very shallow at that time. Even a thin layer of fresh snow on the refrozen ponds was observed. During the last week of measurements in the beginning of June, a tongue of very warm air was shifted from Alaska to the Beaufort Sea. It reached its largest extension over the ocean on 4 June and 5 June 2008, which strongly forced the development of melt ponds.

Aerial photography was carried out with a digital reflex camera and a lens with an angle of view of $114^{\circ}$. A photo was taken every $6 \mathrm{~s}$. In the preprocessing, all photos with sunglint were eliminated, and a cross-track illumination correction was carried out. Subsequently, a supervised classification employing the maximum likelihood method was performed to derive the areal fraction of the five surface classes distinguished: open water, thin ice, bare ice, snow, and melt ponds. Training data was manually defined in the photos. The probability threshold for the classification was set to 0.95 . Pixels, which fell below this threshold were not classified. Only images with a number of unclassified pixels below $5 \%$ were included in the present study. Because of the very shallow 


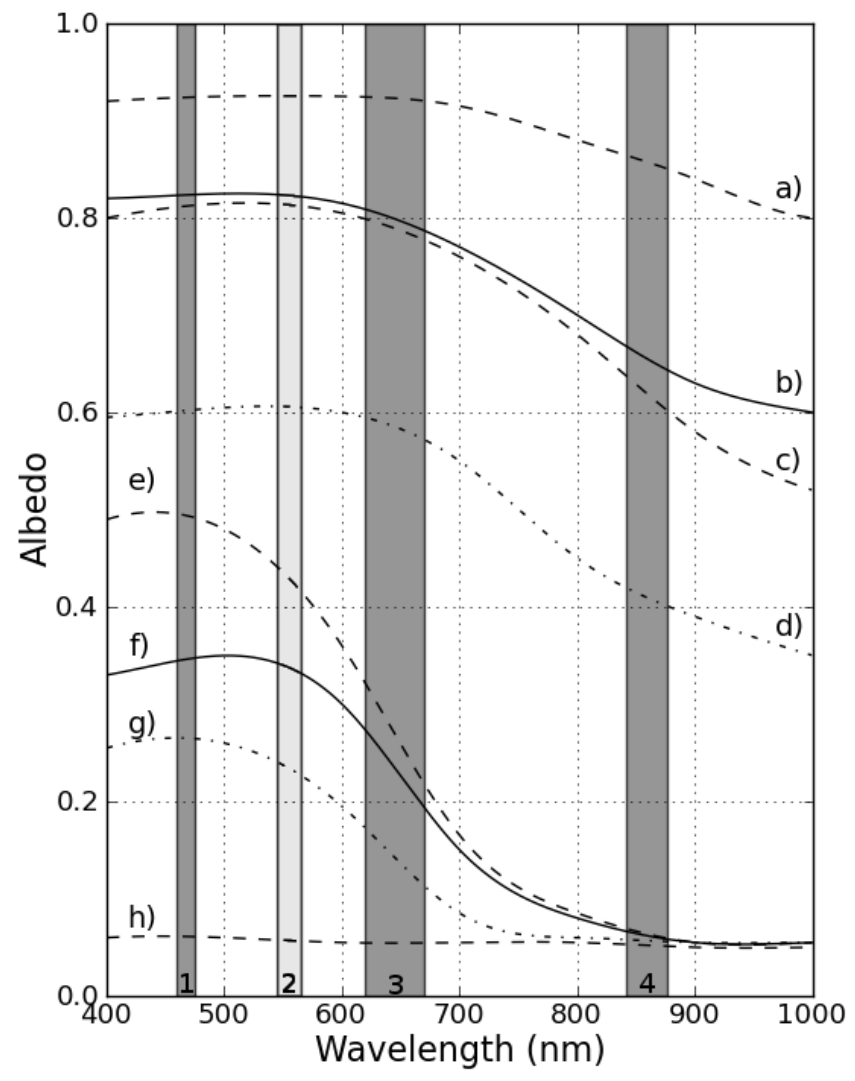

Fig. 2. Spectral albedo values for different surface types on Arctic sea ice: (a) Snow-covered ice (dry snow), (b) cold bare ice, (c) wet snow, (d) melting first year ice, (e) young melt pond, (f) and (g) two types of mature melt ponds, and (h) open water. The gray columns represent the range of the first four MODIS bands. For our study we use the spectral bands 1,3 , and 4 (albedo values after Grenfell and Maykut, 1977).

and partly refrozen ponds, the determination of melt pond fraction based on an analysis of the aerial photos is difficult for days earlier than 4 June 2008. In the present study, we therefore use only photos from two flights performed on 4 June and 7 June 2008 for validation. The flight level of the aircraft determines the surface area covered by the photos. At $1000 \mathrm{~m}$, a photo covers an area of $1.4 \mathrm{~km} \times 2.0 \mathrm{~km}$, and at 30 meters, a photo covers an area of $40 \mathrm{~m} \times 60 \mathrm{~m}$. For further comparison the melt pond set is scaled with the sea ice concentration to obtain the relative melt pond fraction on the Arctic sea ice (see Sect. 3) and afterwards filtered by a Gaussian filter with $\sigma=10$ to smooth the function. We pick every tenth value to avoid oversampling.

Sea ice melt pond statistics and maps over four Arctic Ocean sites during the summers of 1999, 2000, and 2001, derived from visible band imagery from high resolution satellite data with a spatial resolution of $1 \mathrm{~m}$, are mapped from $10 \times 10 \mathrm{~km}^{2}$ satellite scenes (Fetterer et al., 2008). These data sets were analyzed using a supervised maximum likelihood classification to derive either two (water and ice) or three (water, ice, and melt ponds) surface classes (Fetterer et al., 2008). The resulting melt pond data set consists of tables of pond coverage and size statistics for $500 \times 500 \mathrm{~m}^{2}$ cells. Therefore, the spatial resolution of the melt pond set matches the resolution of the MODIS data set. For the comparison with the MODIS melt pond fractions per grid cell, we select only the specific days where MODIS data are available and compare them to the mean of the corresponding high resolution grid cells of one $10 \times 10 \mathrm{~km}^{2}$ satellite scene. Locations of the three sites (i) Beaufort Sea, (ii) north of the Canadian Archipelago, and (iii) Fram Strait are indicated in Fig. 1.

The results of the melt pond observations from the HOTRAX 2005 cruise (Perovich et al., 2009) are also used for validation. The HOTRAX 05 cruise track was a trans-Arctic journey, entering the pack ice on 9 August 2005 at $74^{\circ} \mathrm{N}$, $160^{\circ} \mathrm{W}$ and traveling in the ice until its exit on 27 September 2005 at $77^{\circ} \mathrm{N}, 9^{\circ} \mathrm{E}$. The expedition crossed the Bering, Chukchi, and Beaufort Seas, passed the North Pole on 12 September 2005 and exited the Arctic basin through Fram Strait (see Fig. 1). During the cruise, observations from the bridge of sea ice concentration, relative melt pond fraction, and ice thickness were conducted on an hourly basis and daily mean values were calculated (Perovich et al., 2009). For this study we use only the melt pond observations.

\section{Methodology}

The spectral albedo of sea ice is a function of the wavelength of incident solar radiation (see Fig. 2). Highest albedo values appear in short wavelength range from $400-600 \mathrm{~nm}$ for dry snow. The albedo is decreasing toward longer wavelengths. At $500 \mathrm{~nm}$ melt ponds have albedo values that range between 0.6 for young and shallow ponds and 0.25 for mature ponds. The albedo values for melt ponds depend on the depth and underlying surface of the ponds.

Snow-covered ice, bare ice, wet snow, and melting bare ice, show a smaller reduction in spectral albedo at higher wavelengths than the different types of melt ponds. The albedo of ponded ice is characterized by a decrease between $500 \mathrm{~nm}$ and $800 \mathrm{~nm}$. In this wavelength range the absorption of water becomes a dominant factor, which causes the reduction of the spectral albedo. Above $800 \mathrm{~nm}$ radiation is nearly totally absorbed by the water surface and the underlying ice layer has no influence on the albedo (Grenfell and Maykut, 1977). The spectral curve for open water (Fig. 2h) shows values around 0.06 though the entire spectrum.

Based on the differences of the spectral curves in Fig. 2, in this study we decide to distinguish between three surface types: open water (W), melt ponds (M), and snow and ice (I) (Tschudi et al., 2008; Rösel and Kaleschke, 2011). To calculate the albedo of sea ice on a large scale, the surface-based 
Table 1. Spectral reflectances $\left(r_{i}\right)$ of surface types used in the unmixing algorithm (after Tschudi et al., 2008).

\begin{tabular}{cccccc}
\hline $\begin{array}{c}\text { MODIS } \\
\text { band }\end{array}$ & $\begin{array}{c}\text { bandwidth } \\
{[\mathrm{nm}]}\end{array}$ & $\begin{array}{c}\text { resolution } \\
{[\mathrm{m}]}\end{array}$ & $\begin{array}{c}\text { pond } \\
r_{i}\end{array}$ & $\begin{array}{c}\text { snow/ice } \\
r_{i}\end{array}$ & $\begin{array}{c}\text { open water } \\
r_{i}\end{array}$ \\
\hline 3 & $459-479$ & 500 & 0.22 & 0.95 & 0.08 \\
1 & $620-670$ & 250 & 0.16 & 0.95 & 0.08 \\
2 & $841-876$ & 250 & 0.07 & 0.87 & 0.08 \\
\hline
\end{tabular}

albedo values are weighted with the fraction of their corresponding surface component (Fetterer and Untersteiner, 1998; Tschudi et al., 2008; Perovich et al., 2009).

The so-called areally averaged albedo $\bar{\alpha}$ for larger areas containing three surface types is expressed as

$\bar{\alpha}=\alpha_{\mathrm{W}} A_{\mathrm{W}}+\alpha_{\mathrm{M}} A_{\mathrm{M}}+\alpha_{\mathrm{I}} A_{\mathrm{I}}$

where $A$ is the area fraction per grid cell, $\alpha$ is the wavelengthintegrated albedo and the indices $\mathrm{W}, \mathrm{M}, \mathrm{I}$ stand for the surface types open water, melt ponds, and snow and ice, respectively.

The determination of three surface types of the sea ice covered Arctic Ocean is based upon a spectral unmixing procedure of satellite images and proposed by Tschudi (2005, 2008).

It relies on the following equations:

$$
\begin{array}{r}
A_{\mathrm{W}} r_{\mathrm{W}}\left(\lambda_{1}\right)+A_{\mathrm{M}} r_{\mathrm{M}}\left(\lambda_{1}\right)+A_{\mathrm{I}} r_{\mathrm{I}}\left(\lambda_{1}\right)=R\left(\lambda_{1}\right) \\
A_{\mathrm{W}} r_{\mathrm{W}}\left(\lambda_{3}\right)+A_{\mathrm{M}} r_{\mathrm{M}}\left(\lambda_{3}\right)+A_{\mathrm{I}} r_{\mathrm{I}}\left(\lambda_{3}\right)=R\left(\lambda_{3}\right) \\
A_{\mathrm{W}} r_{\mathrm{W}}\left(\lambda_{4}\right)+A_{\mathrm{M}} r_{\mathrm{M}}\left(\lambda_{4}\right)+A_{\mathrm{I}} r_{\mathrm{I}}\left(\lambda_{4}\right)=R\left(\lambda_{4}\right) \\
A_{\mathrm{W}}+A_{\mathrm{M}}+A_{\mathrm{I}}=1
\end{array}
$$

where $R\left(\lambda_{k}\right)$ is the reflectance of each band $k=1,3$, and 4 , with the corresponding wavelengths $r\left(\lambda_{1}\right)=459-475 \mathrm{~nm}$, $r\left(\lambda_{3}\right)=620-670 \mathrm{~nm}$, and $r\left(\lambda_{4}\right)=841-876 \mathrm{~nm}$, for each MODIS pixel. $A$ is the fractional coverage of each surface type for each band per grid cell, and $r\left(\lambda_{k}\right)$ represents the spectral reflectance for each surface type. The specific reflectance values for the three surface types used for these equations are listed in Table 1.

The set of linear Eq. (2) contains three unknowns $\left(A_{\mathrm{W}}, A_{\mathrm{M}}, A_{\mathrm{I}}\right)$ in four equations, therefore the equations are overdetermined. That means more than one exact solution is possible and thus, we consider the linear Eq. (2) as an optimization problem which needs to be solved in a least-square sense. For the solution of these equation we use a quasiNewton approximation method (Broyden-Fletcher-GoldfarbShanno method).

With the assumption of a three class mixture model and the selection of three surface types, we find, that especially the surface types open water and melt ponds are almost linearly dependent, therefore the set of linear Eq. (2) is not well conditioned. To comply with the physical principles, it is necessary to constrain the interval of the solution between zero and one for each class. This is done by a sigmoid function and implemented as cost function $F_{\text {cost }}$.

$F_{\text {cost }}=[(\boldsymbol{r} \cdot \mathbf{x})-\boldsymbol{R}]+[(1-\tanh (\boldsymbol{x} \gamma)-\tanh ((\boldsymbol{x}-1) \gamma)] w$

where $\boldsymbol{r}$ is the vector of the spectral reflectance values for each surface type, $\boldsymbol{x}$ is a vector of initial guess values for the fractions of surface types, $\boldsymbol{R}$ is the vector of the measured reflectance values $\left(\mathbf{R}=\left[\boldsymbol{R}\left(\lambda_{1}\right), \boldsymbol{R}\left(\lambda_{3}\right), \boldsymbol{R}\left(\lambda_{4}\right)\right]^{T}\right), \gamma$ is a gradient to define the slope of the function at the values zero and one, and $w$ is a weighting factor.

In our function we chose as initial guess values $\boldsymbol{x}=$ $[0.25,0.25,0.25]^{T}, w=0.1$, and $\gamma=150$. However, the results do not depend on the choice of $\boldsymbol{x}$ and $w$. This indicates, that the method is robust and the result is unique.

On the one hand, the implementation of the cost function constrains the range of solutions and enhances the condition of the equation system, but on the other hand, this limitation causes higher computational costs as compared to the solution of the linear Eq. (2) alone.

To speed up processing, we use an artificial neural network (ANN). The use of ANN for remote sensing data has been motivated by the realization that the human brain is very efficient at processing a huge amount of information in a very short time. Neurons in the human brain receive inputs from other neurons and produce an output which is then passed to other neurons. This cross-linking is the basis for the ANN architecture.

A multilayer perceptron (MLP) consists of multiple layers of computational units (= nodes or neurons), usually interconnected in a feed-forward way. That means, each node in one layer has directed connections to the nodes of the next adjacent layer, but has no connections to the nodes of the previous layers. As the signal passes from node to node, it is modified by the weights associated with the connection (Atkinson and Tatnall, 1997). The weight values are established by a supervised learning technique, using a priori information about the actual output corresponding to the input data (Gonzalez Vilas et al., 2011). A typical MLP structure includes an input layer, one or more hidden layers and an output layer. The input layer only distributes the input signal into the network to the nodes of the first hidden layer without processing them. The nodes in the hidden layers and the output layer transform their input signal usually using a nonlinear sigmoid function (Atkinson and Tatnall, 1997).

With the open source package FFNET for Python (Wojciechowski, 2011) we build a feed-forward multilayer perceptron (MLP), composed of an input layer, two hidden layers with 9 neurons in the first and 27 neurons in the second layer, and one output layer (see Fig. 3).

In this case the number of neurons of the input layer is equal number of neurons of the output layer. For our purposes the MLP was trained with back-propagation as learning technique with 5000 learning steps (see e.g. Atkinson and Tatnall, 1997). The amount of layers, neurons and learning 


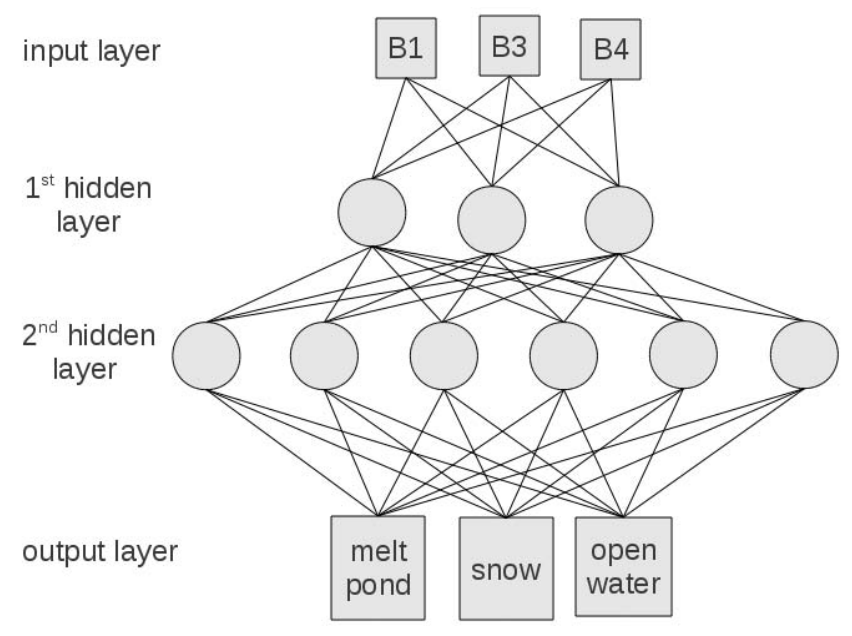

Fig. 3. Architecture of the MLP networks used for this study. The input layer are the MODIS surface reflectances for the three bands 1,3 , and 4 . The hidden layers of the MLP used in our study contains 9 knots in the first layer and 27 knots in the second layer. For reasons of clarity this Figure shows only 3 knots for the first and 6 knots for the second layer. The output layer contains the three classes melt pond, snow, and open water.

steps was determined by following the trial-and-error approach.

To train the ANN, an existing data set of melt ponds needs to be provided as the training data set: We obtain this training data set by solving the Eq. (2) including the above described constraints for a limited amount of pixels from different surface types and different dates. The achieved surface fractions per grid cell for open water, snow and ice, and melt ponds are used to train the ANN.

To asses the consistence and the accuracy of the ANN we perform two tests: For the first test the training data set is used as test data set. For the second test, independent test data sets are selected. The results of the performance regarding consistence and accuracy of the ANN are presented in the following chapter.

The output layer of the ANN provides the surface fractions per grid cell of melt ponds, open water, and snow and ice (Fig. 3). From this output the sea ice concentration $A_{\mathrm{C}}$ is quantified as:

$A_{\mathrm{C}}=1-A_{\mathrm{W}}$

Melt pond fraction on Arctic sea ice is defined as the ponded area relative to the sea ice surface; therefore, it is necessary to scale the retrieved melt pond fraction per grid cell with the sea ice concentration. We define the relative melt pond fraction as:

$\widetilde{A_{\mathrm{M}}}=A_{\mathrm{M}} A_{\mathrm{C}}$

For further analysis, the output data is gridded to $12.5 \mathrm{~km}$ grid. To obtain a reliable data quality, we create a mask from the $12.5 \mathrm{~km}$ grid, which contains at least $50 \%$ cloud free pixels. This masking routine ensures a high data quality of melt pond results and is described in Rösel and Kaleschke (2012).

\section{Results}

\subsection{Accuracy of ANN}

To test the consistence of the ANN, we first apply the trained ANN on the selected training data set and compare the results with the results calculated with the unmixing algorithm.

Thereafter we operate the ANN on eight completely independent test data sets regarding date and region and compare the results as well with the results determined with the unmixing algorithm. The difference between the two methods is for the first case $0.1 \%$, and for the second case less than $1 \%$.

For estimation of the systematic error of this procedure, we perform two further tests on the following assumptions:

- An area of $50 \times 50 \mathrm{~km}^{2}$ around the coordinates $61.5^{\circ} \mathrm{N}$ and $26.0^{\circ} \mathrm{W}$ (Denmark Strait, SW of Iceland) is an open water area in June.

- Melting has not started on day 129 of the year 2008 at a latitude of $82.5^{\circ} \mathrm{N}$ (Markus et al., 2009). An area of $200 \times 100 \mathrm{~km}^{2}$ around the coordinates $82.5^{\circ} \mathrm{N}$ and 92.5 $5^{\circ} \mathrm{W}$ (North of the Canadian Archipelago) is covered with dry snow and/or bare cold ice in the first week of May. No melt ponds are observable.

The test for the open water area results in a relative error of $+0.1 \%$ for the estimated melt pond fraction, for the test on the snowy surface the relative error is $6 \%$.

The fractional coverage of water, ice, melt ponds, and the sea ice concentration is derived for the entire Arctic Ocean by using the trained ANN and MOD09 mosaics.

\subsection{MODIS melt ponds and sea ice concentration}

Figures 4 and 5 show the relative MODIS melt pond fractions and the MODIS sea ice concentrations for the year 2008, both gridded to $12.5 \mathrm{~km}$.

They are displayed here to exemplify the processing of one seasonal cycle. We define a seasonal cycle from the beginning of May (day 129 of the MODIS data set) until the first week of September (day 249 of the MODIS data set). Later in September, when new ice is formed, the relative melt pond fractions increase in areas of new thin ice.

Figure 6 shows the mean melt pond fraction per grid cell for the entire Arctic Ocean within the annual cycles for the years 2000 to 2011. The mean melt pond fraction strongly increase in June. By the end of June, the maximum with a mean melt pond fraction above $15 \%$ is reached, followed by a second maximum at the end of July. In this time period, the 

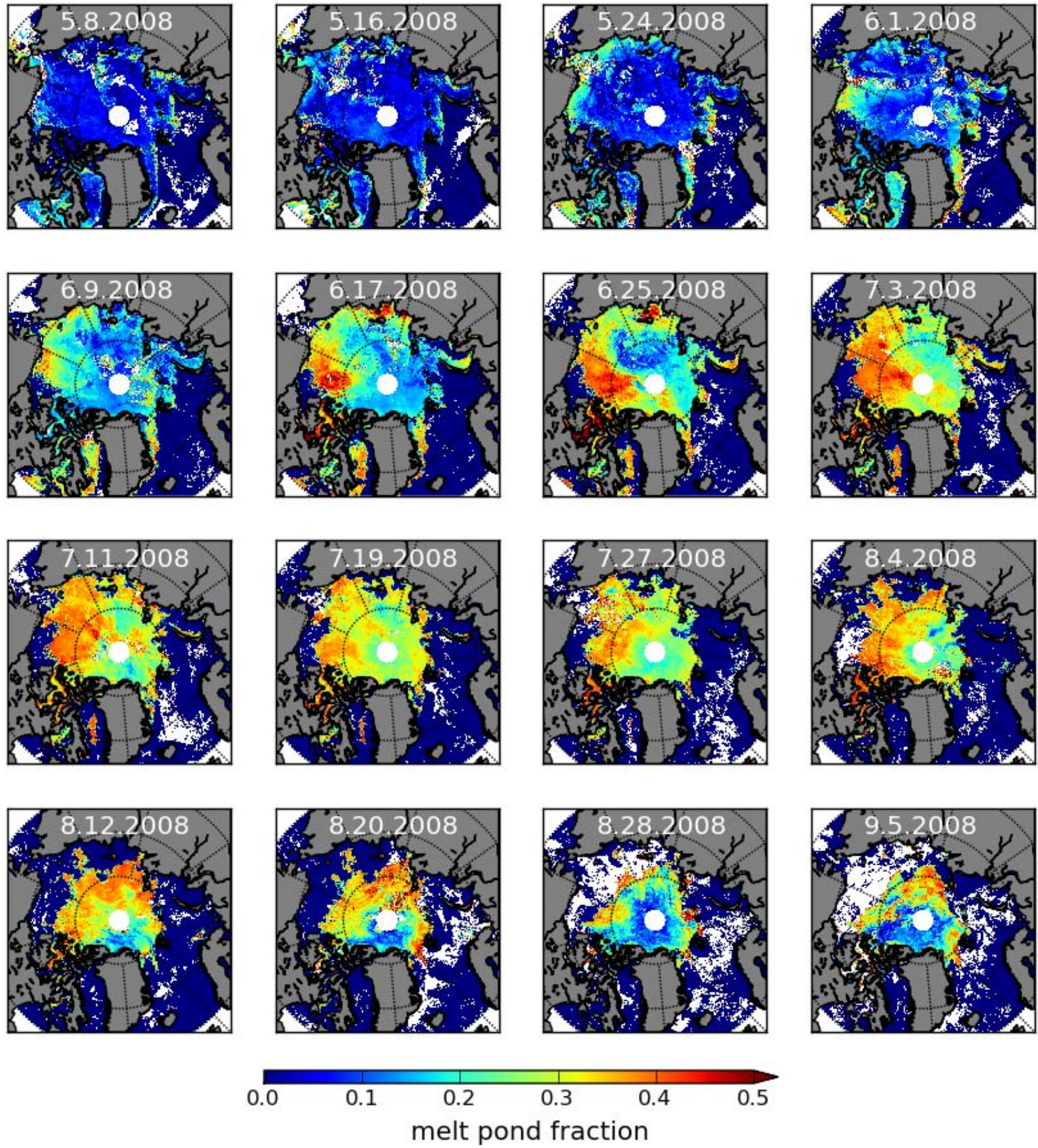

Fig. 4. Seasonal cycle of the relative melt pond fraction from MODIS satellite data for the Arctic for the example of the 2008 melt season. White pixels represent missing data. 

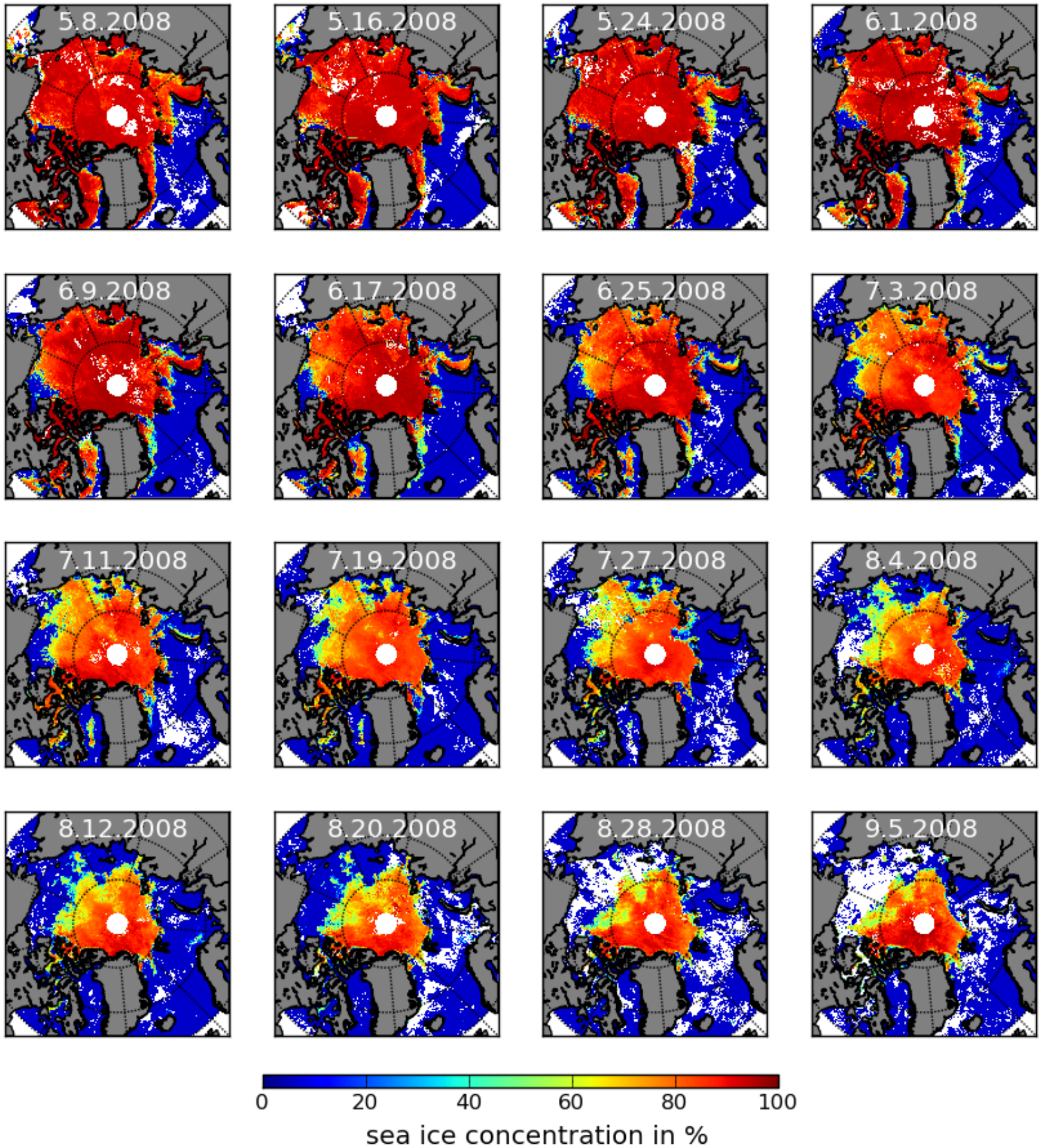

Fig. 5. Seasonal cycle of the sea ice concentration from MODIS satellite data for the Arctic for the example of the 2008 melt season. White pixels represent missing data. 


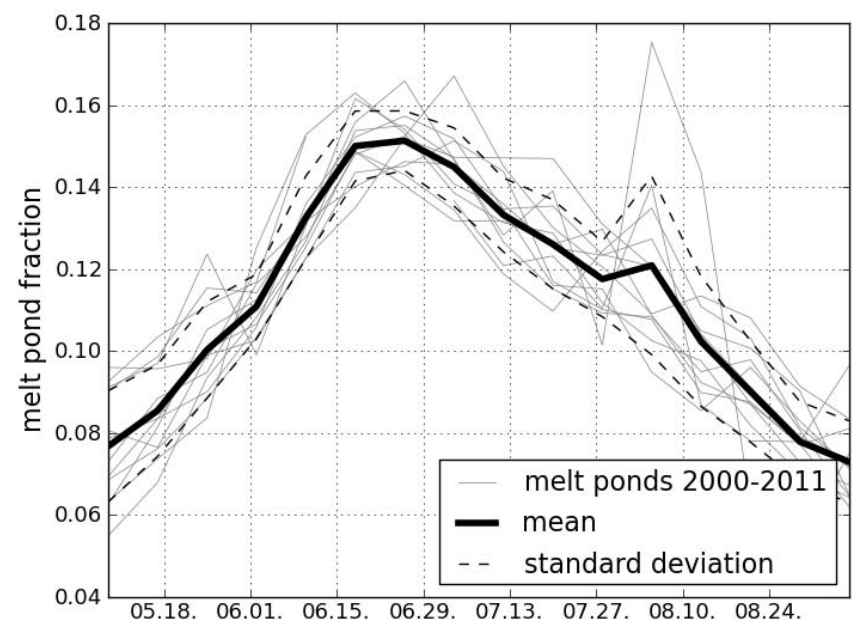

Fig. 6. Weekly mean melt pond fraction per grid cell over the entire Arctic Ocean from 2000 to 2011. The light gray lines display the single years, the solid black line is the average over the last 12 years. Data falling within one standard deviation of the mean are delineated by a pair of dashed lines.

sea ice concentration experiences a steep decline, promoted by surface melt and fragmentation of floes. Thus can induce additionally a flooding of the breaking floes with saline sea water. These flooded surfaces cannot be distinguished from melt ponds and are also classified as ponds (Markus et al., 2003). This effect might be responsible for the second maximum in the melt pond fraction.

The zonal mean of the melt ponds per grid cell for the last 12 years is displayed in Fig. 7 which demonstrates a dependence of the temporal development of melt ponds on geographic latitude. The maximum of the average melt pond fraction is located in mid-July at higher latitudes, between $80^{\circ}$ and $88^{\circ} \mathrm{N}$.

From a case study we demonstrate that we can estimate the influence of melt ponds on the conventional sea ice concentration determination from microwave imagery by comparing them with the calculated MODIS sea ice concentration.

Figure 8 displays in the first three images sea ice concentration from AMSR-E sensor, calculated with the ARTIST Sea Ice (ASI) algorithm (Spreen et al., 2008), the NASATeam 2 (NT2) algorithm (Markus and Cavalieri, 2000), and the Bootstrap (BT) algorithm (Comiso, 1995) for the area of the Canadian Archipelago with values from $50-80 \%$ ice coverage. The fourth image displays MODIS sea ice concentration, whereas sea ice concentration with MODIS indicating values from $90-100 \%$. In the same area, a high relative fraction of melt ponds (up to $70 \%$ ) is determined (bottom image). The ASI algorithm gives, for a $250 \mathrm{~km} \times 100 \mathrm{~km}$ region around the coordinate $72^{\circ} \mathrm{N}$ and $110^{\circ} \mathrm{W}$, a mean sea ice concentration of $45 \%$; the Bootstrap algorithm gives for the same area $55 \%$ sea ice concentration, and the NASA team

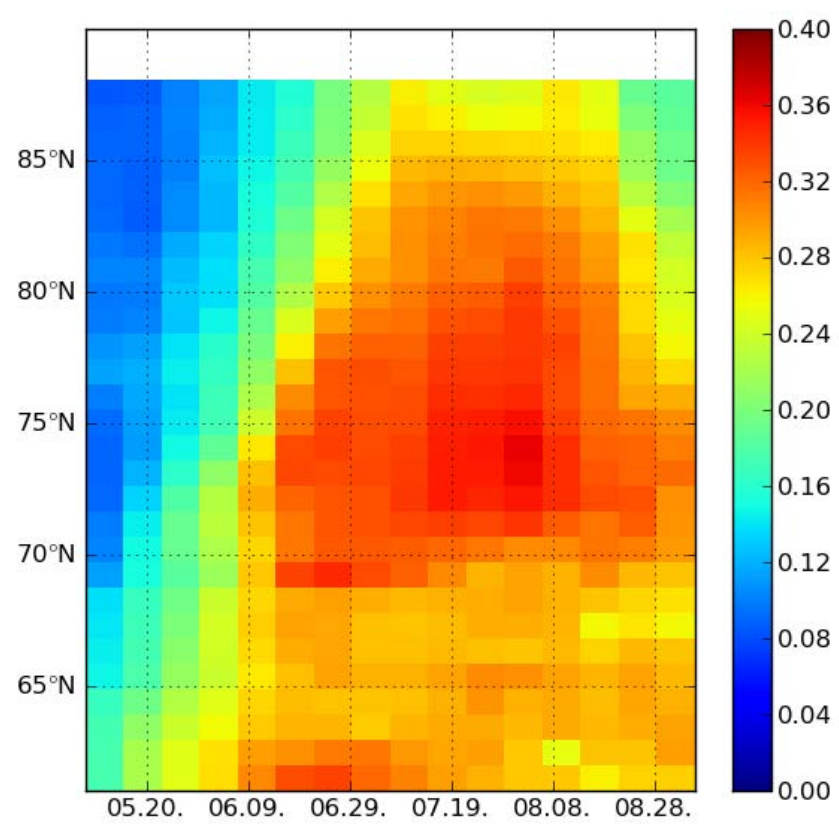

Fig. 7. Zonal mean melt pond fraction per grid cell over the entire Arctic Ocean from 2000-2011.

2 algorithm shows a value of $56 \%$. Compared to the sea ice concentration of $93 \%$ retrieved from the MODIS data, all microwave algorithms underestimate the MODIS sea ice concentration by around $40 \%$.

\subsection{Validation}

For validation we compare the MELTEX melt pond data with MODIS data for 4 June and 7 June 2008 (Figs. 9 and 10). In the true color composite (Figs. 9a and 10a) melt ponds can be determined on the individual ice floes as bluish areas, ranging from light blue to a dark turquoise.

By following the MELTEX flight track in both figures, the changing from medium relative melt pond fractions (20$25 \%)$ to high relative melt pond fractions ( $28 \%$ ) is reflected in the underlying MODIS relative melt pond fractions. The transition to the open water areas is also characterized by a decreasing MODIS relative melt pond fraction.

The flight on 4 June started at 18:03 UTC and ended at 00:09 UTC the next day. After comparison of the daily level 2 MODIS data from 4 June with the individual level 1B acquisitions, we conclude that the corresponding area in the MOD09GA product derives from an acquisition in the early morning (04:00 UTC or 06:15 UTC). The same is valid for the MOD09GA product of 5 June. Because of the rapidly changing meteorological conditions on 4 June in combination with the late flight time (18:03 UTC until 00:09 UTC) and the early acquisitions of the MODIS scenes, we used the MODIS melt ponds determined from the scene from June 5 

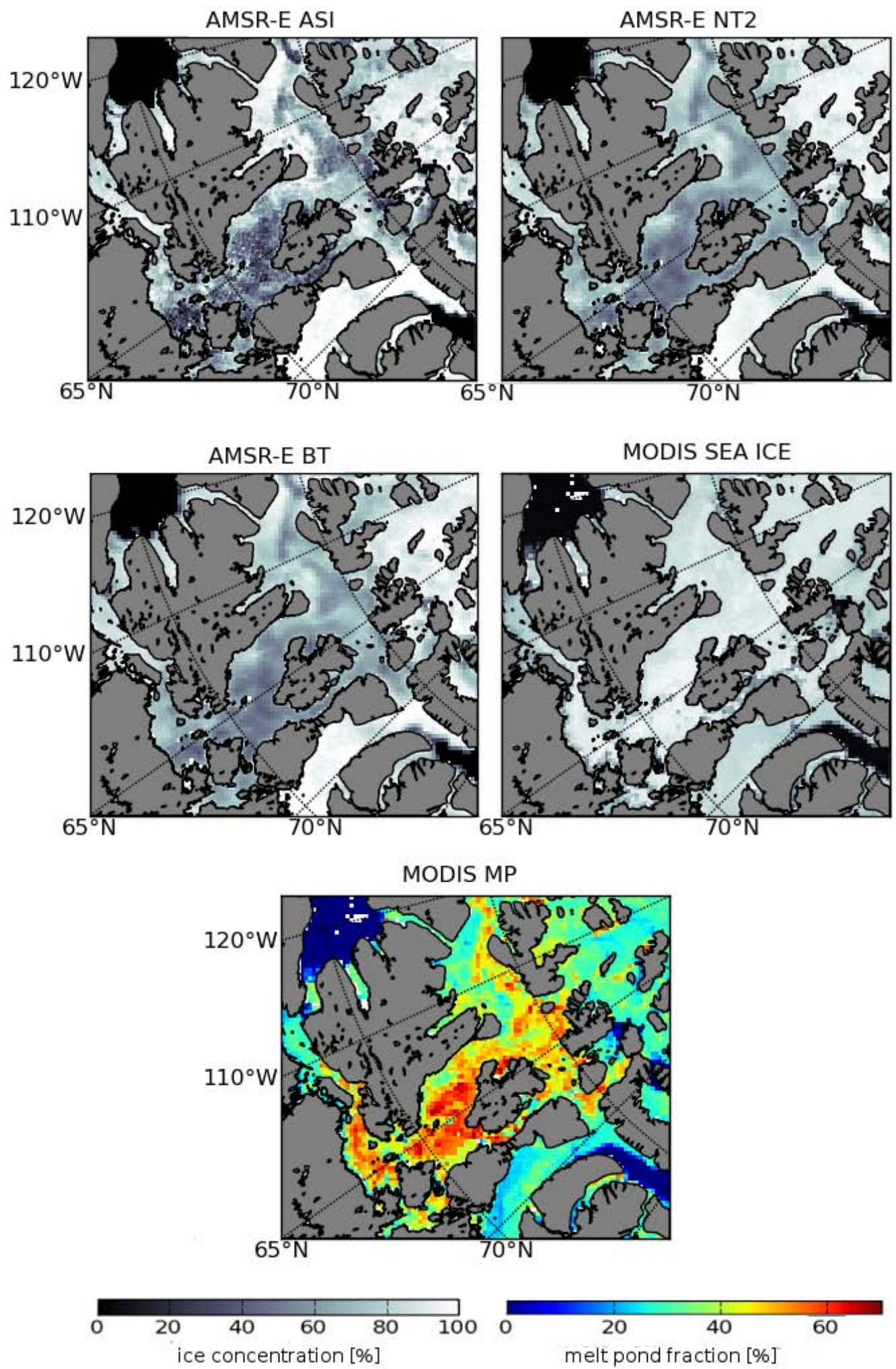

Fig. 8. Comparison of AMSR-E ASI (top left), AMSR-E NASA-Team 2 (top right), AMSR-E Bootstrap (middle left), and MODIS (middle right) sea ice concentrations. In the bottom MODIS relative melt pond fraction is displayed. All images are from 25 May 2008. 

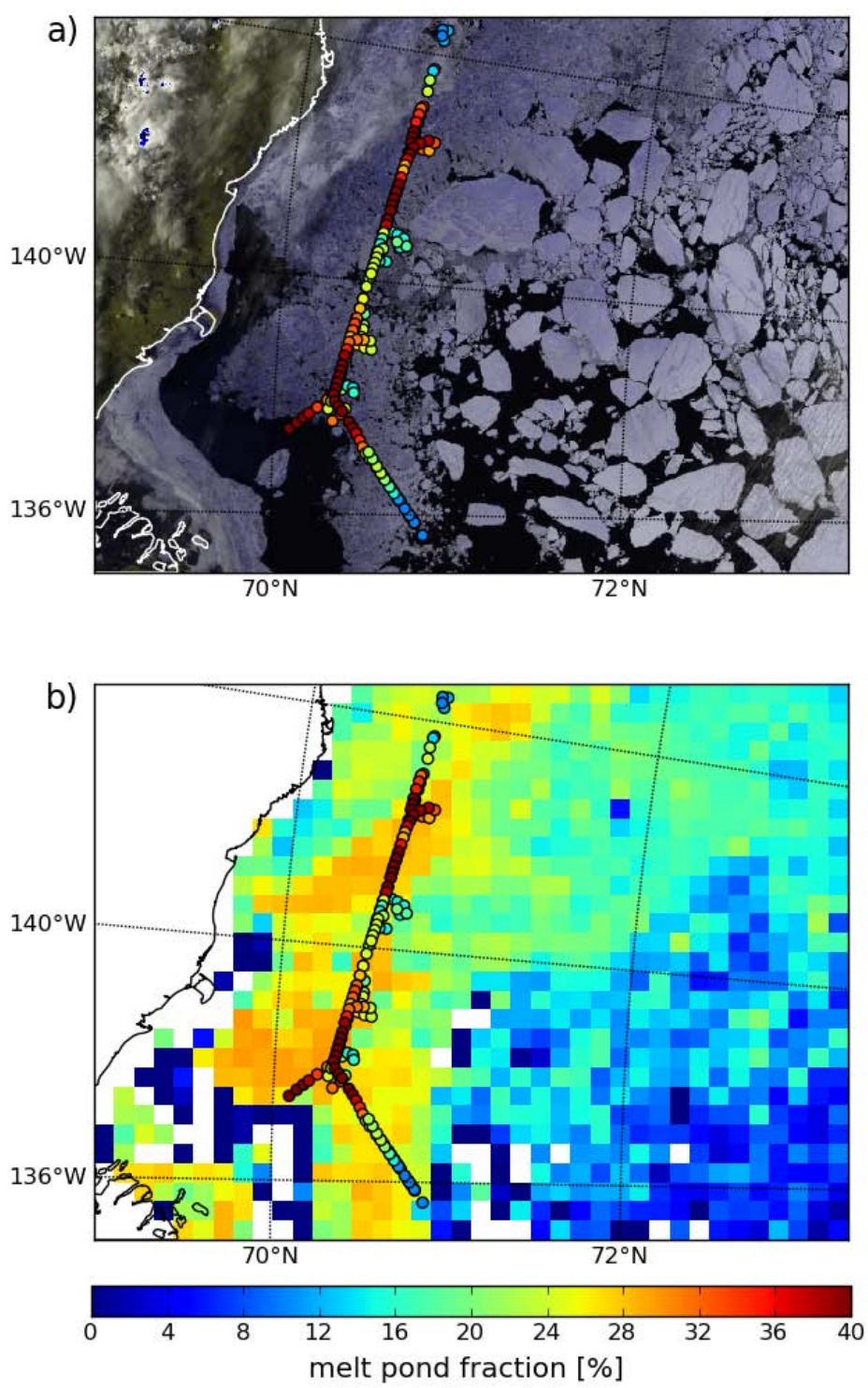

Fig. 9. (a) Spatial overlay of MELTEX melt pond results (dots) on a true color composite of MODIS level 1B data from 4 June 2008, 22:15 UTC. (b) MELTEX melt pond results (dots) from 4 June 2008 overlaid on MODIS relative melt pond fractions from mainly 5 June 2008 (detailed description in the text).

for validation. To fill up the gaps caused by cloud filtering in the MODIS melt pond sets, we use the corresponding pixel from the melt pond sets from days before and after the relevant data (Figs. 9b and 10b).

The average MODIS relative melt pond fraction for the entire flight tracks are $28.4 \% \pm 2.5$ and $21.6 \% \pm 8.1$ for 4 June and 7 June. The corresponding MELTEX relative melt pond fractions are with $26.4 \% \pm 11.5$ and $19.3 \% \pm 13.5$ slightly lower. The calculated root mean square errors (RMSE) for the dates 4 June and 7 June are $11.2 \%$ and $10.6 \%$ accordingly.
Figure 11 shows the comparison of NSIDC melt pond data versus MODIS melt pond data per grid cell. One part of the data (mainly Beaufort data and one data point from the Canadian site) corresponds well with the MODIS melt pond data, the other part of the data shows lower values than the MODIS data. The RMSE for the data of all sites and both years amounts $10.7 \%$ with a coefficient of determination of $R^{2}=0.28$

The HOTRAX melt pond observations used for our validation study are daily means with standard deviation. In Fig. 12 the observations are plotted versus MODIS relative melt pond fractions. 

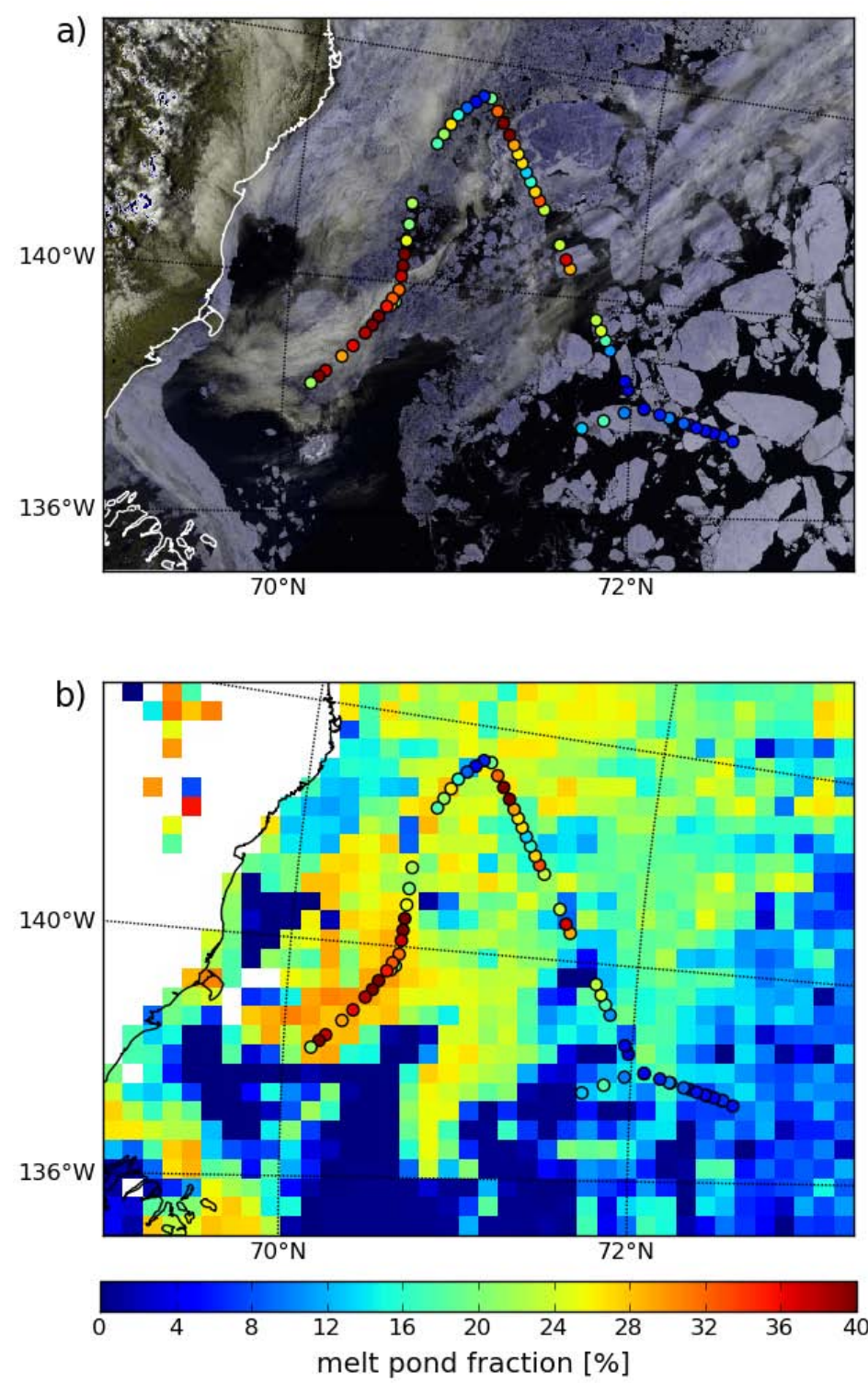

Fig. 10. (a) Spatial overlay of MELTEX melt pond results (dots) on a true color composite of MODIS level 1B data from 7 June 2008, 21:25 UTC. (b) MELTEX melt pond results (dots) from 7 June 2008 overlaid on MODIS relative melt pond fractions from mainly 7 June 2008 (detailed description in the text).

The compared mean values are distributed evenly with a coefficient of determination of $R^{2}=0.45$ and a determined RMSE of $3.8 \%$. The observed differences may result from geolocation errors or time differences between ship observation and satellite acquisition. Moreover, there is no information about the accuracy of the ship observation data.

\section{Discussion}

The determination of the melt pond fraction of the entire Arctic sea ice over a multi-annual time period is important to estimate the contribution of the melt ponds to the ice-albedo feedback mechanism. The above described method allows us to derive daily and weekly data sets of the melt pond fraction, as well as for the sea ice concentration from MODIS MOD09 data. We use the daily data sets to validate MODIS melt pond fractions and the weekly data sets for generating the time series for the entire Arctic.

Since the weekly data set is a composite of selected pixels from the daily acquisitions, especially with low cloud cover fraction and other atmospheric influences, this product may represent only the conditions of a specific day in one week. 


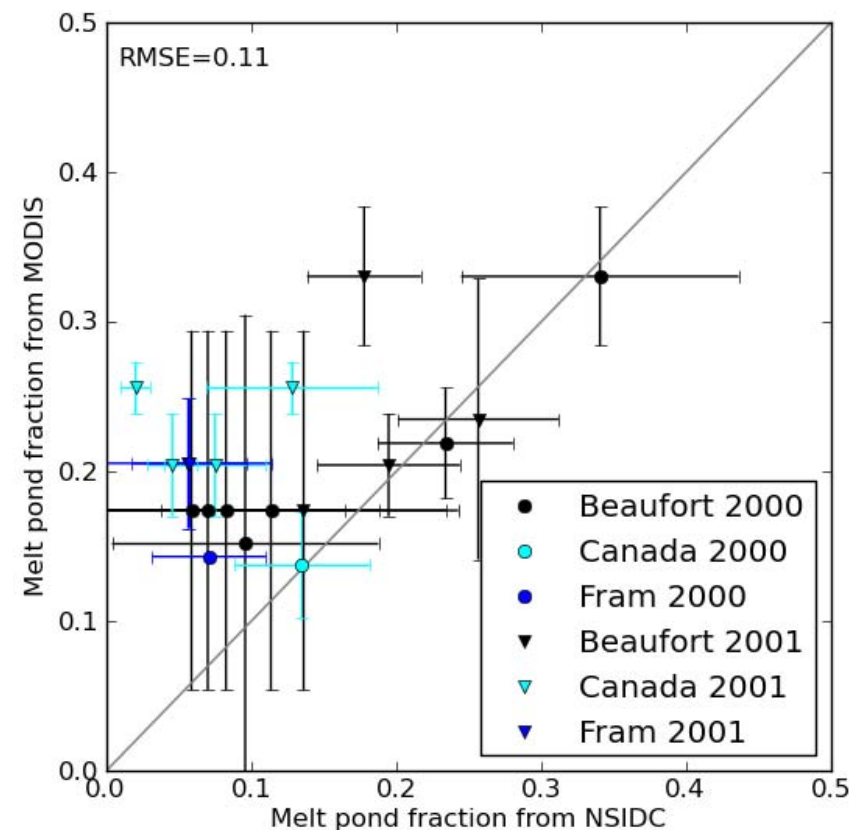

Fig. 11. Values from the MODIS melt pond product plotted versus NSIDC melt pond statistics for the years 2000 and 2001 and the three sites (i) Beaufort Sea, (ii) North of the Canadian Archipelago, (iii) and Fram Strait. The error bars are the standard deviation of the gridding from the results to $10 \times 10 \mathrm{~km}^{2}$ for NSIDC data and to $12.5 \times 12.5 \mathrm{~km}^{2}$ for the MODIS data. The RMSE is $10.7 \%$ and the coefficient of determination is $R^{2}=0.28$.

The comparison of MODIS melt pond fractions with aerial photos and sea ice observations from different locations in the Arctic shows good agreement. This demonstrates that the technique to estimate the fraction of melt ponds performs well.

The observed differences between validation data and MODIS data may result from the different spatial resolution, from geolocation errors and/or time differences between observations and satellite acquisition. The validation with the MELTEX data demonstrate that MELTEX data has more variability than the MODIS data - this may result from the relatively coarse resolution of $500 \mathrm{~m}$ per MODIS pixel used as the basis for this product compared to the averaged size of melt ponds of about $15 \mathrm{~m}^{2}-60 \mathrm{~m}^{2}$ (Perovich et al., 2002b). Additionally, intra-daily variations of the melt pond fractions due to the strong diurnal cycle of melt-water production rates are observed at least during the first part of of the melt season (Eicken et al., 2004). Therefore, satellite and and surface based observations strongly depend on the point in time of the observation and discrepancies in the melt pond fractions of both are not surprising. The comparison with the NSIDC data results in generally higher MODIS melt pond values and a poor coefficient of determination with $R^{2}=0.28$. In this case we compare the average melt pond fraction of a $10 \times 10 \mathrm{~km}^{2}$ scene from NSIDC with a $12.5 \times 12.5 \mathrm{~km}^{2}$ grid

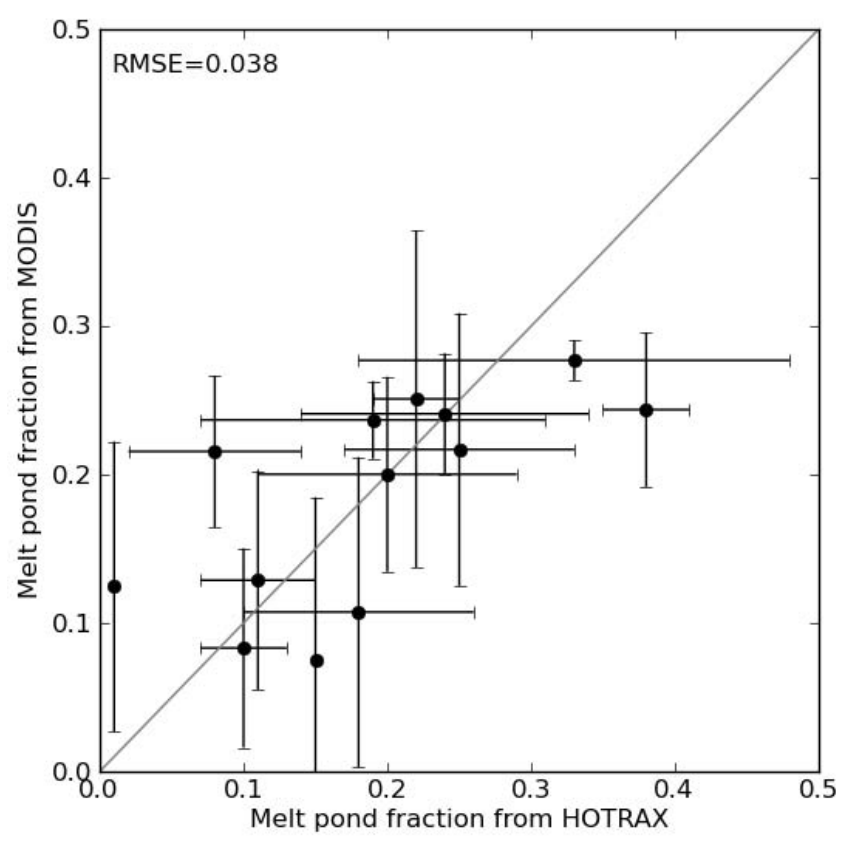

Fig. 12. Values from the MODIS melt pond product plotted versus ship observations from the HOTRAX cruise in 2005. The error bars are the standard deviation of the daily mean for the HOTRAX data and the gridding to $12.5 \times 12.5 \mathrm{~km}^{2}$ for the MODIS data. The RMSE is $3.8 \%$ and the coefficient of determination is $R^{2}=0.45$.

cell of the MODIS melt pond fraction. Here, we use weekly data sets for validation instead of daily data sets. From the daily data sets we have noticed, that a poor coverage of valid pixels in the validation area exists, whereas the weekly data sets provide more cloud free pixels. However, this leads to the problem, that the corresponding pixels in the MODIS data are probably from a different date than the NSIDC data. This may be a reason for the higher values of the MODIS fractions.

As shown in Huck et al. (2007) a proper atmospheric correction of reflectance data is necessary for the surface determination from satellite data. Due to the general lack of relevant atmospheric data for the Arctic region, potential sources of errors are to be assumed in the atmospheric correction and the influence of the viewing geometry and the solar angles. The BRDF correction of the MOD09 product does not extend across all areas of the Arctic ice cover, in particular not over the deep ocean, because of the non-stationary sea ice surface. For most of the areas model results for first-year and multiyear ice are used as a priori estimates of the BRDF (personal communication with Crystal Schaaf, NASA). It is to consider, if atmospheric correction approaches for land surfaces of lower latitudes as used by Huck et al. (2007) could perform more realistic surface reflectance values than the atmospheric correction approach used for the MOD09 products, which assumes ocean conditions for sea ice areas. 
Our assumption of the three-surface-class model also causes uncertainties regarding the different fractions, because in reality the Arctic sea ice cover is a mosaic of various surface types. Furthermore, it is necessary to think about an expansion of the surface-class model and consider further classes like wet snow, bare ice or sediment-laden surfaces.

Especially over highly reflecting surfaces like sea ice, the used cloud mask may have problems. To enhance data quality for further studies, a data mask with a defined threshold or weighting of involved pixels can be applied after the gridding routine. In the $500 \mathrm{~m}$ grid, single pixels with a high melt pond signal occur often within cloudy fields or at the edges of the cloud mask. We assume, that these pixels are a misclassified cloud signal. To minimize the influence of these misclassified pixels, the above introduced technique eliminates at least grid cells with a low data quality (see Sect. 3). However, the existing problem of cloudy pixel in the initial dataset can impact the melt pond fraction and should be considered.

Figure 7 shows a zonal increase of the melt pond fraction per grid cell correlating to the increasing solar elevation and with a maximum of the average melt pond fraction per grid cell located in the higher latitudes, between $80^{\circ}$ and $88^{\circ} \mathrm{N}$, although the melt period is shorter in high latitudes. This was also observed by Tschudi et al. (2008) and may be caused by a larger sea ice concentration and a thicker ice coverage, which allows less runoff. Therefore more water is retained to form melt ponds (Tschudi et al., 2008).

The pattern of melt pond distribution in early summer (Fig. 4) of areas with an increased relative melt pond fraction in the beginning of June indicates the ice free areas later in September. This agrees with the statements of Perovich et al. (2002b, 2011b), that early occurrence of melt ponds has a strong influence on the formation of open water areas. Clearly visible is also the appearance of homogeneous areas with a very high relative melt pond fraction up to $70 \%$ at the end of June on the flat first year ice in the Canadian Archipelago. The decrease of melt ponds in the week starting from August 28, 2008 was caused by a cold air advection from Greenland with temperatures far below the freezing point. The weather situation changed on 5 September 2008, as warm continental air masses from Siberia caused further melting in the Siberian Arctic and the Fram Strait.

The method described here is based on optical satellite data - therefore melt pond fractions can only be identified from cloud free data. In the autumn results, the three-class model with open water, melt ponds, and snow and ice fractions cannot resolve the spectral signature of thin ice properly and assigns this signature to the melt pond class. Therefore, in autumn when new ice is formed, the algorithm misclassifies areas of thin ice, such as at the ice edge, as ponded ice. For this reason our melt pond data set ranges from beginning of May (day 129) only until the first week of September (day 249).
The multi-annual melt pond data set has a variety of potential applications, like to test and improve the parameterization of melt ponds in climate models, the analysis of the inter-annual variability as well as the trends of melt processes and their influence on the sea ice-albedo feedback mechanism. Additionally to the melt pond data set, we archive a sea ice concentration data set from MODIS data. This sea ice concentration data set, in combination with the melt pond data set, is a valuable basis for quantifying the error caused by melt features in sea ice concentration data derived from passive microwave imagery.

In general, the influence of melting sea ice, especially of melt ponds on the sea ice surface, causes uncertainties in microwave-based retrieval algorithms and is documented by Cavalieri et al. (e.g. 1990); Steffen and Schweiger (e.g. 1991); Comiso and Kwok (e.g. 1996). To which extent there is a relation between MODIS melt ponds and AMSR-E sea ice concentrations needs to be identified in a further study, as well as the strength of the influence of MODIS ponds on sea ice concentrations. As shown in Fig. 8, the MODIS sea ice concentration product has potential to estimate the influence of melt ponds on the sea ice concentration determination from microwave sensors like AMSR-E. In this case study, all AMSR-E algorithms are clearly underestimating the actual sea ice concentration by around $40 \%$.

\section{Conclusions}

In this study we present a procedure to generate multi-annual melt pond and sea ice concentration data sets for extensive areas from MODIS satellite data as shown by example example for the melt cycle in the year 2008.

The MODIS surface reflectance values are described by a set of linear equations, that are not well conditioned and need to be solved with an optimization method. By solving the equations we retrieve three surface fractions: open water, snow and ice, and melt ponds. To constrain the interval of the solution between zero and one, a cost function is introduced.

To accelerate the processing, we use a trained artificial neural network. Testing the performance of the ANN as described in Sect. 4 results in stable results with a maximal error of $+6 \%$ for melt pond fractions.

The mean melt pond fraction per grid cell for the entire Arctic Ocean derived from MODIS satellite data of the last 12 years shows a strong increase in June. By the end of June the maximum with a mean melt pond fraction above $15 \%$ is reached, followed by a second maximum in end of July.

The zonal mean of the melt pond fraction per grid cell depends on the temporal development of melt ponds regarding the geographical latitude. The maximum of the average melt pond fraction is situated in the higher latitudes, between $80^{\circ}$ and $88^{\circ} \mathrm{N}$. 
The retrieved MODIS sea ice concentration shows, that sea ice concentration derived from microwave sensors underestimates the actual sea ice concentration by $40 \%$.

In this paper we present a method to retrieve for the first time a multi-annual data set of melt pond fraction and sea ice concentration derived from MODIS satellite data for the entire Arctic. The developed MODIS melt pond data set and the sea ice concentration data of the last twelve melt cycles provide a profound basis for further studies. The melt pond data set introduced here is provided through the Integrated Climate Data Center (ICDC, http://icdc.zmaw.de).

Acknowledgements. We thank Donald K. Perovich from the Cold Regions Research and Engineering Laboratory (CRREL) for providing the HOTRAX melt pond data, and Florence Fetterer from NSIDC for her efforts in providing more melt pond statistics. Wolfgang Dierking, Christof Lüpkes and Jörg Hartmann from the AWI participated in the MELTEX aircraft campaign in 2008 and provided useful information for our study. We also want to mention namely both student workers from AWI, Bruno Schyska and Pascal Schwarz for the analysis of the aerial photos of the MELTEX campaign. Stefan Kern and Remon Sadikni from the CliSAP-Integrated Climate Data Center (ICDC) took care about the quality control and published the data online. Additionally, we thank the scientific editor and the reviewers for their profound comments and suggestions. The work was founded by a scholarship of the International Max-Planck-Research-School for Maritime Affairs in Hamburg. Additional support was provided by the Cluster of Excellence CliSAP (EXC177), University of Hamburg, founded through the German Science Foundation (DFG).

The service charges for this open access publication have been covered by the Max Planck Society.

Edited by: H. Eicken

\section{References}

Atkinson, P. M. and Tatnall, A. R. L.: Introduction - Neural networks in remote sensing, Int. J. Remote Sens., 18, 699-709, doi:10.1080/014311697218700, 1997.

Birnbaum, G., Dierking, W., Hartmann, J., Lüpkes, C., Ehrlich, A., Garbrecht, T., and Sellmann, M.: The Campaign MELTEX with Research Aircraft "POLAR 5" in the Arctic in 2008, Berichte zur Polar- und Meeresforschung/Reports on Polar and Marine Research, 593, 3-85, 2009.

Brandt, R. E., Warren, S. G., Worby, A. P., and Grenfell, T. C.: Surface Albedo of the Antarctic Sea Ice Zone, J. Climate, 18, 3606-3622, 2005.

Cavalieri, D. J., Burns, B. A., and Onstott, R. G.: Investigation of the effects of summer melt on the calculation of sea ice concentration using active and passive microwave data, J. Geophys. Res., 95, 5359-5369, 1990.

Comiso, J. C.: SSM/I Sea Ice Concentrations Using the Bootstrap Algorithm, NASA Reference Publication, 1380, 1-50, 1995.

Comiso, J. C. and Kwok, R.: Surface and radiative characteristics of the summer Arctic sea ice cover from multisensor satellite ob- servation, Journal of Geophysical Research, 101, 28397-28416, 1996.

Curry, J. A., Schramm, J. L., and Ebert, E. E.: Sea Ice-Albedo Climate Feedback Mechanism, J. Climate, 8, 240-247, 1995.

Eicken, H., Krouse, H. R., Kadko, D., and Perovich, D. K.: Tracer studies of pathways and rates of meltwater transport through Arctic summer sea ice, J. Geophys. Res., 107, doi:10.1029/2000JC000583, 2002.

Eicken, H., Grenfell, T. C., Perovich, D. K., Richter-Menge, J. A., and Frey, K.: Hydraulic controls of summer Arctic pack ice albedo, Journal of Geophysical Research, 109, C08007, doi:10.1029/2003JC001989, 2004.

Eisenman, I. and Wettlaufer, J. S.: Nonlinear threshold behavior during the loss of Arctic sea ice-albedo, PNAS, 106, 28-32, doi:10.1073/pnas.0806887106, 2009.

El Naggar, S., Garrity, C., and Ramseier, R.: Sea Ice Meltpond Morphology and Size Distribution as Determined from Line Scan Camera Local Measurements in the Arctic, IAPSO Proceedings XXI General Assembly, 19, Honolulu, Hawaii, 5-12 August, 1995.

Fetterer, F. and Untersteiner, N.: Observations of melt ponds on Arctic sea ice, J. Geophys. Res., 103, 24821-24835, 1998.

Fetterer, F., Wilds, S., and Sloan, J.: Arctic sea ice melt pond statistics and maps, 1999-2001, Digital Media (ftp), http://nsidc.org/ data/g02159.html, 2008.

Gonzalez Vilas, L., Evangelos, S., and Torres Palenzuela, J. M.: Neural network estimation of chlorophyll a from MERIS full resolution data for the coastal waters of Galician rias (NW Spain), Remote Sens. Environ., 115, 524-535, 2011.

Grenfell, T. and Maykut, G.: The optical properties of ice and snow in the Arctic Basin, J. Glaciol., 18, 445-463, 1977.

Grenfell, T. C. and Perovich, D. K.: Spectral Albedos of Sea Ice and Incident Solar Irradiance in the Southern Beaufort Sea, J. Geophys. Res., 89, 3573-3580, 1984.

Holland, M. M., Bitz, C. M., and Tremblay, B.: Future abrupt reductions in the summer Arctic sea ice, Geophys. Res. Lett., 33, L23503, doi:10.1029/2006GL028024, 2006.

Huck, P., Light, B., Eicken, H., and Haller, M.: Mapping sedimentladen sea ice in the Arctic using AVHRR remote-sensing data: Atmospheric correction and determination of reflectances as a function of ice type and sediment load, Remote Sens. Environ., 107, 484-495, doi:10.1016/j.rse.2006.10.002, 2007.

Kurtz, N. T., Markus, T., Farrell, S. L., Worthen, D. L., and Boisvert, L. N.: Observations of recent Arctic sea ice volume loss and its impact on ocean-atmosphere energy exchange and ice production, J. Geophys. Res., 116, C04015, doi:10.1029/2010JC006235, 2011.

Markus, T. and Cavalieri, D. J.: An enhancement of the NASA Team sea ice algorithm, IEEE T. Geosci. Remote, 38, 13871389, 2000.

Markus, T., Cavalieri, D. J., Tschudi, M. A., and Ivanoff, A.: Comparison of aerial video and Landsat 7 data over ponded sea ice, Remote Sens. Environ., 86, 458-469, doi:10.1016/S00344257(03)00124-X, 2003.

Markus, T., Stroeve, J. C., and Miller, J.: Recent changes in Arctic sea ice melt onset, freezeup, and melt season length, J. Geophys. Res., 114, C12024, doi:10.1029/2009JC005436, 2009.

Maslanik, J., Drobot, S., Fowler, C., McPhee, G., Emery, W., and Barry, R.: On the Arctic climate paradox and the continuing role 
of atmospheric circulation in affecting sea ice conditions, Geophys. Res. Lett., 34, L03711, doi:10.1029/2006GL028269, 2007.

Morassutti, M. P. and LeDrew, E. F.: Albedo and Depth of Melt Ponds on Sea-Ice, Int. J. Climatol., 16, 817838, doi:10.1002/(SICI)1097-0088(199607)16:7;817::AIDJOC44;3.0.CO;2-5, 1996.

Nicolaus, M., Gerland, S., Hudson, S. R., Hanson, S., Haapala, J., and Perovich, D. K.: Seasonality of spectral albedo and transmittance as observed in the Arctic Transpolar Drift in 2007, J. Geophys. Res., 115, C11011, doi:10.1029/2009JC006074, 2010.

Notz, D.: The future of ice sheets and sea ice: Between reversible retreat and unstoppable loss, PNAS, 106, 20590-20595, doi:10.1073/pnas.0902356106, 2009.

Perovich, D. K.: The Optical Properties of Sea Ice, CRREL Monograph, 96-1, 25 pp., 1996.

Perovich, D. K. and Tucker, W. B. I.: Arctic sea-ice conditions and distribution of solar radiation during summer, Ann. Glaciol., 25, 445-450, 1997.

Perovich, D. K., Grenfell, T. C., Light, B., and Hobbs, P. V.: Seasonal evolution of the albedo of multiyear Arctic sea ice, J. Geophys. Res., 107, 8044, doi:10.1029/2000JC000438, 2002a.

Perovich, D. K., Tucker III, W. B., and Ligett, K. A.: Aerial observations of the evolution of ice surface conditions during summer, J. Geophys. Res., 107, 8048, doi:10.1029/2000JC000449, 2002b.

Perovich, D. K., Light, B., Eicken, H., Jones, K. F., Runciman, K., and Nghiem, S. V.: Increasing solar heating of the Arctic Ocean and adjacent seas, 1979-2005: Attribution and role in the ice-albedo feedback, Geophys. Res. Lett., 34, L19505, doi:10.1029/2007GL031480, 2007.

Perovich, D. K., Grenfell, T. C., Light, B., Elder, B. C., Harbeck, J., Polashenski, C., Tucker III, W. B., and Stelmach, C.: Transpolar observations of the morphological properties of Arctic sea ice-albedo, J. Geophys. Res., 114, C00A04, doi:10.1029/2008JC004892, 2009.

Perovich, D. K., Jones, K. F., Light, B., Eicken, H., Markus, T., Stroeve, J., and Lindsay, R.: Solar partitioning in a changing Arctic sea-ice cover, Ann. Glaciol., 52, 192-196, 2011a.

Perovich, D. K., Richter-Menge, J. A., Jones, K. F., Light, B., Elder, B. C., Polashenski, C., Laroche, D., Markus, T., and Lindsay, R.: Arctic sea-ice melt in 2008 and the role of solar heating, Ann. Glaciol., 52, 355-359, 2011b.

Romanov, I. P.: Atlas of Ice and Snow of the Arctic Basin and Siberian Shelf Seas, Backbone, New York, 2 Edn., 1995.

Rösel, A. and Kaleschke, L.: Comparison of different retrieval techniques for melt ponds on Arctic sea ice from Landsat and MODIS satellite data, Ann. Glaciol., 52, 185-191, 2011.

Rösel, A. and Kaleschke, L.: Exceptional melt pond occurrence in the years 2007 and 2011 on the Arctic sea ice archived from MODIS satellite data, J. Geophys. Res., in press, 2012.
Sankelo, P., Haapala, J., Heiler, I., and Eero, R.: Melt pond formation and temporal evolution at the station Tara during summer 2007, Polar Research, 29, 311-321, doi:10.1111/j.17518369.2010.00161.x, 2010.

Serreze, M. C.: Rethinking the sea-ice tipping point, Nature, 471, 47-48, doi:10.1038/471047a, 2011.

Serreze, M. C., Barrett, A. P., and Cassano, J. J.: Circulation and surface controls on the lower tropospheric air temperature field of the Arctic, J. Geophys. Res., 116, D07104, doi:10.1029/2010JD015127, 2011.

Spreen, G., Kaleschke, L., and Heygster, G.: Sea ice remote sensing using AMSR-E 89-GHz channels, J. Geophys. Res., 113, C02S03, doi:10.1029/2005JC003384, 2008.

Steffen, K. and Schweiger, A.: NASA team algorithm for sea ice concentration retrieval from Defense Meteorological Satellite Program special sensor microwave imager: comparison with Landsat satellite imagery, J. Geophys. Res., 96, 971-987, 1991.

Tietsche, S., Notz, D., Jungclaus, J. H., and Marotzke, J.: Recovery mechanisms of Arctic summer sea ice, Geophys. Res. Lett., 38, L02707, doi:10.1029/2010GL045698, 2011.

Tschudi, M., Curry, J., and Maslanik, J.: Determination of areal surface-feature coverage in the Beaufort Sea using aircraft video data, Ann. Glaciol., 25, 434-438, 1997.

Tschudi, M., Curry, J., and Maslanik, J.: Airborne observations of summertime surface features and their effect on surface albedo during FIRE/SHEBA, J. Geophys. Res., 106, 15335-15344, 2001.

Tschudi, M. A., Maslanik, J. A., and Perovich, D. K.: Melt pond coverage on Arctic sea ice from MODIS, in: Proceeding, Amer. Met. Soc. 8th Conf. on Polar Meteorology and Ocean, San Diego, CA, 8-14 January, 2005, 2005.

Tschudi, M. A., Maslanik, J. A., and Perovich, D. K.: Derivation of melt pond coverage on Arctic sea ice using Modis observation, Remote Sens. Environ., 112, 2605-2614, doi:10.1016/j.rse.2007.12.009, 2008.

Vermonte, E. F., Kotchenova, S. Y., and Ray, J. P.: MODIS Surface Reflectance User's Guide, MODIS Land Surface Reflectance Science Computing Facility, version 1. 2 Edn., http://modis-sr. 1tdri.org/products/MOD09_UserGuide_v1_3.pdf, 2008.

Warren, S. G.: Optical Properties of Snow, Rewiews of Geophysics and Space Physiks, 20, 67-89, 1982.

Wojciechowski, M.: FFNET: Feed-forward neural network for python, http://ffnet.sourceforge.net/,accessdate:20October2011, 2011.

Yackel, J. J., Barber, D. G., and Hanesiak, J. M.: Melt ponds on sea ice in the Canadian Archipelago: 1. Variability in morphological and radiative properties, J. Geophys. Res., 105, 22049-22060, doi:10.1029/2000JC900076, 2000. 